Meta

Journal des traducteurs

Translators' Journal

\title{
Translating the Bible Inclusively
}

\section{Paul Ellingworth}

Volume 32, numéro 1, mars 1987

La traduction biblique

Bible Translation

URI : https://id.erudit.org/iderudit/002702ar

DOI : https://doi.org/10.7202/002702ar

Aller au sommaire du numéro

Éditeur(s)

Les Presses de l'Université de Montréal

ISSN

0026-0452 (imprimé)

1492-1421 (numérique)

Découvrir la revue

Citer cet article

Ellingworth, P. (1987). Translating the Bible Inclusively. Meta, 32(1), 46-54.

https://doi.org/10.7202/002702ar

Ce document est protégé par la loi sur le droit d'auteur. L'utilisation des services d'Érudit (y compris la reproduction) est assujettie à sa politique d'utilisation que vous pouvez consulter en ligne.

https://apropos.erudit.org/fr/usagers/politique-dutilisation/
Cet article est diffusé et préservé par Érudit.

Érudit est un consortium interuniversitaire sans but lucratif composé de l’Université de Montréal, l'Université Laval et l'Université du Québec à Montréal. Il a pour mission la promotion et la valorisation de la recherche. https://www.erudit.org/fr/ 


\section{TRANSLATING THE BIBLE INCLUSIVELY}

PAUL ELLINGWORTH

University of Aberdeen, Aberdeen, U.K.

A male, professionally engaged in advising Bible translators, comes to the question of inclusive (non-sexist, non-male-oriented) language with presuppositions which to some extent counterbalance one another. On the one hand, as a human being, I have learned a great deal from the feminist movement, and support its attempt to ensure equal justice for both halves of the human race. On the other hand, as a translation consultant, I approach with some suspicion a movement which seems occasionally in danger of distorting the content of the Bible. In this respect, some aspects of the feminist movement may be compared with Jewish pressure to eliminate authentically antiJewish features from the New Testament, or with fundamentalist pressure to harmonise real differences between parallel biblical narratives.

There is no doubt that there is a real problem. To begin long ago and far away, the non-Hindu reader who does not read Sanskrit may well be puzzled when he reads, in Radhakrishnan's translation of the Bhaghavadgita, Arjuna's question :

What is the description of the man who has ... firmly founded wisdom... ? How should the man of settled intelligence speak, how should he sit, how should he walk?

and Krishna's reply :

When a man puts away all the desires of his mind..., and when his spirit is content in itself, then he is called stable in intelligence (11.54-55).

Are Arjuna and Krishna speaking about human beings in general, or is the ideal only for men?

A generation ago, when in June 1954 the London Times published a special supplement on the Bible, Eric Fenn, then Editorial Secretary of the British and Foreign Bible Society, could begin his contribution :

The British and Foreign Bible Society ... exists ... to make the Scriptures available to all $m e n$ in the languages they speak and at a price they can afford to pay. The founders of the society were men ... (30; my underlining)

without apparently realising, and certainly without indicating, that he had glided in a few lines from the inclusive to the male sense of the word "men".

More recently, Joann Haugerud, in her introduction to an inclusive translation of parts of the New Testament, asks with understandable indignation :

When Jesus called Peter, Andrew, James and John to become "Fishers of men" (Mark 1.17), did Jesus mean that they would set out to catch male humans only ${ }^{1}$ ?

The problem involves five main factors : on the one hand, the biblical culture and languages; on the other hand, present-day receptor languages and cultures; and between them, the translation process itself.

These factors differ considerably in their degree of variability. The source languages and culture are in principle given and static, though in practice our knowledge 
and apprehension of them vary to some extent, not least in response to the challenge of current pressure for the use of inclusive language. The factors of receptor languages and cultures are so variable that our treatment in the present article must be selective. We shall in fact concentrate on the use of inclusive language in modern Bible translation, particularly of the New Testament ${ }^{2}$ in the English-speaking world, where the linguistic aspect of the campaign has achieved remarkable results ${ }^{3}$.

Even within this restricted area, however, the situation is rapidly changing. One of the most delicate problems for the present-day translator, as for any other writer, is that of judging the moment at which a neologism introduced under feminist pressure has achieved general acceptance among the intended readers. Until comparatively recently, it was accepted, explicitly by linguists 4 and passively by the wider community, that the English "man" had three main senses : KJV) ;

a) adult human being (count noun : "the way of a man with a maid" ; Prov. 30.19

b) member of the human race (count noun, usually generic singular : "shall a man be more pure than his maker?" ; Job $4.17 \mathrm{KJV}$ );

c) the human race, mankind (proper noun : "the sabbath was made for man", $\mathrm{Mk}$. $2.27 \mathrm{KJV}$; often spelt "Man").

Confusion can easily arise between meanings $a$ ) and $b$ ), because $a$ ) can occur in all the contexts appropriate to $b$ ), though not vice versa.

This position is now widely challenged, and even the hitherto neutral term "mankind" is coming to be avoided in favour of the neologism "humankind". The feminist challenge to this usage may be understood in various ways. Perhaps the most likely interpretation is that, because the first meaning is distinctively male, the other meanings are contaminated by male associations, and should therefore be avoided. A similar development seems to be taking place in the case of "native". For some years, the noun was avoided as pejorative, especially in racial contexts, but the adjective in such phrases as "native speaker", "native language" was accepted. More recently, even the adjective is coming under a cloud, and phrases such as "mother tongue speaker" are being heard more frequently. Something similar may be understood to he happening to "man".

For the purposes of the present discussion, translation principles may be taken as relatively constant, in the sense that modern Bible translators, like translators of other literary texts, generally conceive of their task as being essentially that of reproducing as closely as possible the meaning of the original text, without omission, addition or distortion, using the natural resources of another language. The feminist challenge does not affect this principle qua principle, but it has brought about significant and apparently lasting changes in English usage which affect the ways in which the principle is applied. The translation process can therefore be represented, as far as its aim and intention are concerned, as the equal sign in a simple equation :

$$
\mathrm{SC} \times \mathrm{SL}=\mathrm{RL} \times \mathrm{RC}
$$

in which $\mathrm{SC}$ is the source culture, SL a source language, RL a given receptor language, and $\mathrm{RC}$ its ambient culture.

The sharpest controversy often arises between the extreme terms of the equation ; that is, where features of biblical (especially but not only Old Testament) culture are perceived as conflicting with current claims for equal rights for women, and there is consequent pressure to remove such features from translations of the scriptures.

The argument could in principle take at least three forms. First, a feminist translator could perceive male dominance in aspects of the biblical culture, and remove them in order to salvage the relevance of the Bible for a different age. Secondly, such a trans- 
lator could attempt to de-emphasize such features, on the grounds that they were accepted as normal in the original culture, but would attract disproportionate and negative attention in a translation for modern use. Thirdly, a translator could argue that the male orientation of biblical culture is only apparent, and that a modern translation should bring out the underlying universality of the Bible, as being for all cultures and for men and women alike.

These options for the feminist argument have varying degrees of plausibility, but they all have their limitations. In response to the first, it must be firmly and repeatedly emphasized that translation is not transculturation. For example, it is doubtless shocking for many people nowadays that the last of the Ten Commandments (Ex. 20.17) should list a man's wife alongside his slaves, cattle, donkeys, and "anything else that he owns" ; but that is the plain meaning of the text, and it is the translator's function to communicate this, not to obscure it.

The second argument is more subtle, and must be considered case by case in every text in which the question of male orientation arises. Some parts of the Bible are unquestionably sexist by modern standards, but this aspect of the source culture functions more often as a presupposition than as an overt statement ; in other words, the biblical authors assume male orientation in the course of making statements about something else. In such situations, the translator has the delicate and difficult task of conveying the meaning of the statement, while neither neglecting the presuppositions on which it is based, nor translating in such a way that the alien presupposition shouts down the message.

The third argument, in the form stated, is too general to be useful, but it serves as a reminder that contrasts between the source and receptor cultures, in particular apparent instances of male orientation, must be carefully checked at the linguistic level, with a view to discovering whether the apparent sexism arises from the text itself, or from traditional translations.

Most of this article will therefore be concerned with the minutiae of linguistic analysis. It is through language that cultural presuppositions become apparent, and no translator can do justice to the original culture except by careful examination of the language in which it is expressed. It is therefore all the more necessary to state in advance that some problems are too general to be solved by an analysis of the text and its immediate context ; they require reference to other parts of the corpus (in this case, the $\mathrm{Bi}$ ble), and to the widest possible range of background information.

For example, early editions of Today's English Version ${ }^{5}$ translated Heb. 9.16 with beautiful simplicity : "Where there is a will, it has to be proved that the man who made it has died". The Greek for "the man who made [the will]" is a masculine participle which could in principle refer either to a man or to a woman. Later editions of GNB, recognizing this, accordingly translated : "In the case of a will, it is necessary to prove that the person who made it has died..." This may be justified on the grounds that the main point of the statement is not the sex of the testator. It does, however, almost certainly involve mild cultural adjustement. There is some evidence that, in biblical times, women could own and inherit property (cf. Num. 27.1-11), albeit under strict conditions (cf. Num. 36.1-12). It was however rare, though not unknown, for women to make wills ; so referentially, TEV's first thoughts were probably correct.

Most of the time, however, the crucial battle is fought on linguistic terrain, even if cultural factors may have a legitimate influence, so to speak, on the formulation of the ensuing peace treaty. Central to this discussion, though by no means exhausting it, is the question of terms referring to men, and generally to human beings. 
Languages differ widely in this respect, and it is an open question whether these linguistic differences correspond to greater or less male domination in the culture. The question is the more general one of whether a language specifies sex optionally or obligatorily. For example, English, French, and many other languages, when referring to immediate kin of the same generation, must specify sex, at least in common language : apart from the highly technical "sibling", the only terms available are "brother" and "sister". In German, the common language term Geschwister is available to refer to brothers and sisters alike. In Chinese, reference to age is compulsory, while reference to sex is optional : "brothers and sisters" thus becomes "older and younger siblings".

The problem most commonly arises with terms referring to men. At the cost of some simplification, it can be said that Hebrew has two main terms, $\bar{a} d \bar{a} m$ and $i s h$, of which the first refers to human beings generally, while the second tends to refer to adult males. The broadly corresponding terms in Greek are anthropos and aner; the Septuagint Greek translation of the Old Testament normally (with exceptions, particularly in Proverbs) translates ish by anerr, while anthropos is freely used to translate either of the Hebrew terms. A similar distinction is found in Latin between homo and vir; and among modern languages in German, between Mensch and Mann. Traditionally, these options have not been available in English, French, and some other languages ; in English, " man" has had to do duty for both, especially in common language.

It should therefore be emphasized that the problem at this level is linguistic rather than cultural. It is difficult to maintain, for example, that society in English-speaking countries is traditionally more male-dominated than in German-speaking areas. But English has greater difficulty in responding to the feminist challenge in linguistic terms, because it does not have convenient and ready-made common-language expressions to refer to women and men without distinction. "Human beings" lies somewhat toward the upper reaches of common language ; in addition, it may misleadingly suggest a contrast with non-human beings such as angels or animals. "People", even when its use as a synonym of "nation" is set aside, suffers from the disadvantage that it is generally used with some kind of qualification : "many people", "people who matter"; or at least as a grammatical subject : "people don't like to be kept waiting". To native speakers of English, "fishers of people", in a translation of Mark 1.17, sounds like an awkward neologism, and "fishers of women and men", the ILL solution, like a slogan. The problem, however, is highly language-specific ; in German, the natural equivalent is Menschenfischern, "fishers of people", and the same is true of Bantu languages, for example Swahili Wavuvi wa Watu $^{6}$. In Greenlandic, there is no problem at all, since distinctions between "he", "she", and "it" are optional. In the Greek, both "fishers" and "people" could in principle be either women or men, though culturally it is more likely that fishers would be men, and referentially the people to whom Jesus gave this title were in fact male.

A simple exercise will show in greater detail both the unnecessarily male-oriented tendency of traditional translations of the New Testament, and some of the difficulties which face the present-day translator in his or her attempts to do better in this respect. Arndt and Gingrich's Greek-English Lexicon of the New Testament ${ }^{7}$ is a standard work which can scarcely be charged with feminist bias ; it does, however, as the Authorised (King James) Version (KJV) did not, recognise that in many senses and contexts, the Greek anthropos refers to women and man alike. It is instructive to analyze translations of the 63 texts (excluding parallels) cited by Arndt-Gingrich for its first three meanings of anthropos. Modern versions vary according to whether they translate these occurrences using (a) "man" or "men", or (b) some not specifically male term such as "man- 
kind", "human(ly)", "others", or "everyone". Statistics of the various translations consulted do not prove anything, but may indicate a trend :

Translation

Authorised Version

Jerusalem Bible

Revised Standard Version

New English Bible

Today's English Version NT

New International Version

Good News Bible

$\begin{array}{ccccc}\text { Abbrev. } & \begin{array}{c}\text { 1st } \\ \text { ed. }\end{array} & \begin{array}{c}\text { Ed. } \\ \text { consulted }\end{array} & \text { No } & \text { \% } \\ & & & \text { (a) } & \text { (a) } \\ \text { KJV } & 1611 & \text { n.d. } & 100 & 63 \\ \text { JB } & 1968 & 1968 & 57 & 36 \\ \text { RSV } & 1946 & 1971 & 79 & 50 \\ \text { NEB } & 1961 & 1970 & 60 & 38 \\ \text { TEV } & 1966 & 1971 & 65 & 41 \\ \text { NIV } & 1973 & 1973 & 75 & 47 \\ \text { GNB } & 1976 & 1984 & 38 & 24\end{array}$

These figures suggest a gradual move away from unnecessarily male-oriented language. Within this general movement, JB was ahead of its time, possibly because, as a Roman Catholic translation, it had to overcome a lighter weight of vernacular biblical tradition. NIV, by contrast, marked a reaction in this respect, while TEV/GNB underwent a thorough revision to reduce the amount of male reference.

Space does not allow us to examine all Arndt-Gingrich's 63 examples in detail, but some particularly interesting or difficult occurrences may be briefly noted, following Arndt-Gingrich's classification.

\section{Human beings as a class}

John 16.21 : KJV "... for joy that a man is born into the world". Here the main problem is not that of male reference, but the collocational clash between "man" (adult male) and "born". JB and NEB surprisingly retain "man", perhaps implying "a baby which is potentially an adult". But this is surely tortuous : the meaning is more probably "a (new) human life", without specifying sex or (except by implication in the context) age.

Mark 9.31 : KJV "The Son of Man is delivered into the hands of men". The context speaks by implication of the activity of God, in contrast to human beings. A narrowing of the reference to "men", as in all the translations consulted, is referentially justified, since all those active in the trial and crucifixion of Jesus were, as far as we know, men.

Rom. 2.9 : KJV "Tribulation and anguish, upon every soul of man that doeth evil ; of the Jew first, and also to the Gentile..." There is no reason, linguistic, contextual, or cultural, for limiting God's condemnation to males. Similarly in Rev. 9.4.

2 Cor. 4.2 : KJV "... commending ourselves to every man's conscience in the sight of God". There may have been restrictions on allowing women to preach in the first Christian congregations ( 1 Cor. 14.34-36), but there is no suggestion that they were excluded from listening to the apostolic preaching : "every one's conscience" is clearly the meaning.

Rev. 21.17 : KJV "four cubits, according to the measure of a man, that is, of the angel". The meaning is odd but clear : although the scene is set in heaven, the angel is using the ordinary human cubit as a unit of measurement.

In another group of texts, human beings are contrasted with other forms of life, such as fish (Mk. 1.17 and parallels), sheep (Mt. 12.12), various classes of beings (1 Cor. 15.13), and a human voice is contrasted with the normal bray of a donkey (2 Pet. 2.16; cf. Numbers 22.21-35). One or two texts in this group pose minor difficulties : in Mt. 
12.12, RSV "of how much more value is a man than a sheep !", the discussion has been sparked off by Jesus' healing of an individual man, but by this time, the reference is probably general. In Rev. 9.7, where RSV translates "[the locusts'] faces were like human faces", TEV, perhaps seeing a contrast with the following words, "their hair like women's hair", retains the traditional translation "their faces were like men's faces" ; but what is more probably in focus is the contrast between the human face and the animal body of the apocalyptic locust. Rev. 13.18, KJV "the number of the beast ... is the number of a man", sounds superficially like "the measure of a man" in Rev. 21.17, discussed above. RSV accordingly translates "a human number". But what is a "human number" ? The writer of Revelation seems to move in a universe throughout which numbers have transcendent significance, and are not merely human signs. It is more likely that "the number of a man" means the number reached by adding the numerical values of the letters of his name. If so, the reference is to a particular historical figure, probably a ruler, and if so almost certainly a man.

\section{Human beings contrasted with angels}

In principle, such texts should pose few problems : the contrast between men and angels is neither more nor less sharp than that between women and angels. In 1 Cor. 4.9, for example, RSV "we are made a spectacle to the world, and to angels, and to men", there is no suggestion that women did not join in mocking the apostles ; so it is surprising that only GNB adopts here the translation "mankind". 1 Cor. 13.1, RSV "Though I speak with the tongues of men and of angels...", is essentially similar. What is clearly intended is a contrast between human and angelic language or eloquence. Yet all translations consulted retain the traditional "men". In a well-known and poetic passage, modern translators doubtless felt that "men" could still carry the meaning "mankind". It remains to be seen how long this usage can survive under the pressure for inclusive language.

\section{Human beings as distinct from God}

Heb. 13.6 = Ps. 118.6 : RSV "The Lord is my helper... what can man do to me ?"

The reference is to human beings in general. All translations except GNB have

"man"; GNB's "anyone" could be criticised as too wide, since it could include nonhuman beings. "What can any human being do to me ?" gives the meaning, but is a little heavy for a poetic quotation. In $1 \mathrm{Tim}$. 2.4, the idea of God wanting everyone to be saved could scarcely be more general, yet all translations consulted except JB and GNB have "man".

\section{As a means of address}

The vocative anthropos is used to indicate a close relationship, usually but not always friendly, between the speaker and the person addressed. The relationship, not the sex of the addressee, is the essential point. Thus, in Lk. 5.20, JB, TEV/GNB and JB translate "my friend", where Jesus is speaking to a man. In Rom. 2.1, Paul addresses in the same way an imaginary opponent, who in principle could be either male of female, though in the setting of rabbinic debate one would assume him to be a man. Here, most modern translations avoid male reference. TEV/GNB's "my friend" sounds too warm : NEB and NIV have simply "you", and JB leaves the address untranslated.

\section{People, fellow human beings}

Here there is a strong tendency to use "men". In Mt. 5.13, only TEV/GNB has "people", for those who tread salt underfoot, and in Mk. 3.28, only GNB has "people" 
for "sons of men", i.e. human beings, who are forgiven. Male reference is clearly inappropriate.

\section{Human physical and moral weakness}

In the two halves of Rom. 5.18, Paul writes of the bad effects of Adam's sin, and the good effects of Christ's righteous action, extending to the whole human race, without sexual or other distinction. Despite this broad reference, most translations use "man" : JB has "everyone", and GNB "mankind". In Mt. 10.17, where Jesus speaks of disciples being handed over to courts of justice, all translations consulted have "men"; yet the handing over does not seem to demand a (male) official, any more than, say, the betrayal of Samson by Delilah, or of Jesus by Judas.

"In a human way", "from a human standpoint"

Such translations represent the Greek phrase kata anthrōpon, one of a number of set phrases which modern translations often recognize as not having male reference. In 1 Cor. 9.8, for example, several versions have "human" ; TEV/GNB speaks of "everyday examples".

\section{"Anyone"}

In a wide range of contexts, anthrōpos is virtually equivalent to "one" or "anyone". In his original cultural setting, the shepherd of Mt. 18.12, who loses one of his hundred sheep, may be assumed to be male ; the wording does not specify this, but all translations consulted have "man". 1 Tim. 5.24, however, contrasts "the sins of some people", which "are plain to see", with those of others, which "are seen only later" (GNB). The first half of the verse uses anthropos, the second only a pronoun; yet the reference is clearly equally broad. Most modern translations except NIV recognize this by translating "people". In some such situations, however, the wording can be neutral, but the reference, at least implicitly, male. One example is when Caiaphas speaks of letting "one person die for the people" (Jn. 11.50). He is enunciating a general principle, and nothing in the Greek requires male reference ; but the implied reference to Jesus is so strong that all versions translate "one man".

Such examples could be multiplied several times from the New Testament alone, and the issue, even there, is much wider than the translation of anthropos. Yet it is already clear that the feminist challenge is proving a positive stimulus to modern Bible translators to re-examine the text and revise their presuppositions. Much inconsistency remains, and there are genuine unsolved problems, especially on the frontier between explicit and implicit information, or between language and situation.

So far, we have made no reference to a central theme of the feminist challenge to the English Bible, namely the translation of terms referring to God, and to a lesser extent to the other persons of the Trinity. Yet these are the most striking feature of ILL. For example, "Lord", as applied to God or to Jesus, is replaced by "Sovereign"; "Father", referring to God, is preceded by "Mother and" ; "Son of Man" is translated "the Human One" ; and "kingdom of God" is replaced by "realm of God". These and other departures from RSV are indicated by footnotes, and discussed in an appendix.

To say that such expressions do not normally pose a translational problem is not to minimise their importance ; on the contrary, it is to indicate that the real problem lies at a deeper level. On the level of translation, there seems no real alternative to recognizing that, within the setting of their own culture, the biblical writers used predominanly male language in speaking directly about God, though female language is sometimes used in similes (Isa. 63.13) and parables (Luke 15.8-10). At the level of translation, male reference must be preserved where it is present in the text, or wholesale transculturation 
will ensue. But at a deeper level, any reader of the Bible, whether male or female, must constantly learn to penetrate beneath the (not only male, but) human language in which the Bible speaks of God, to the divine reality underlying all the imagery.

As has been indicated, usage in English, and perhaps in some other languages, is still very fluid in the area under discussion. It would therefore be both premature and presumptuous to attempt to draw permanently valid conclusions. It may however be helpful, both for Bible translators and for those who read their translations, to list some of the pitfalls to be avoid as far as possible by the sensitive translator.

1. The translator must never override the linguistic evidence. If the linguistic evidence is such as to indicate a high probability of male reference, there must be even stronger evidence on the opposite side before the translator can safely conclude that a particular text constitutes an exception.

2. Some of the linguistic evidence may be implicit in the immediate context. This should be taken just as seriously as explicit linguistic evidence. For example, when, in German, one says "zwei Menschen heiraten" ("two people get married"), it is generally safe to assume that one is male and the other female. Similarly, though with less certainty, the "two [people] in one bed" of Luke 17.34 may be assumed to be a man and his wife.

3. Where a problem cannot be settled on linguistic grounds alone, background information on the biblical culture must be taken into account.

4. One of the translator's most difficult tasks is to reproduce the elements of meaning in the text, not only without addition or subtraction, but also with the right emphasis and in the right perspective. The translator needs to become aware of elements which, though entirely secondary in the original text, risk attracting disproportionate emphasis in translation, because they conflict with the modern readers' cultural expectations. Some degree of de-emphasis may be in order in such cases. This is in fact the reverse of transculturation : it is an attempt to preserve equivalence of meaning across a cultural gap ${ }^{8}$.

5. Closely related to this is what one might call the translator's capacity for seeing the main point. As several examples have indicated, it is not enough to discover whether the people referred to in a given text are male or female; it is necessary also to ask whether the argument turns on their sex, or on some other factor such as their humanity. In such situations, it may be legitimate, without transculturation, to translate a term having male reference by an inclusive expression.

6 . The translator must keep constantly under review the state of current usage in the receptor language. For example, in English, he must be able to judge the moment at which, for his intended readers, "humankind" becomes a more acceptable form than "mankind".

7. The purpose of this whole operation is not to void the Bible of its cultural strangeness, nor to exploit a current linguistic fashion, nor even to use the Bible as a weapon in the cause of equal human rights. The purpose of the operation, as of translation generally, is to hold the meaning (including the cultural content) constant, while making the freest possible use of the natural resources of the receptor language, to meet the needs of the intended readers?.

Notes

1. Joann Haugerud (1977) : The Word for Us. A translation of John and Mark, Romans and Galatians, Seattle.

2. For the Old Testament, cf. W. Vogels (1978) : "It is not good that the Mensch should be alone ; I will make him/her a helper fit for him/her (Gen. 2:18)", Église et théologie 9, 9-35; P. Ellingworth (1978) : "They were both naked, the Mensch and his/her woman ?", Eglise et théologie 9, $505 \mathrm{f}$. 
3. See, in addition to Joann Haugerud's work cited in note 1 (1983) : An Inclusive Language Lectionary. Readings for Year A. Prepared for experimental and voluntary use in churches by the Inclusive Language Lectionary Committee appointed by the Division of Education and Ministry, National Council of the Churches of Christ in the USA, Atlanta, etc. Henceforth referred to as ILL. Cf. the review articles in Interpretation 38/1 (January 1984), 64ff.

4. This paragraph and the next are greatly indebted to Dr. Stephen Parkinson of the Department of Linguistics, University of Aberdeen.

5. Henceforth TEV for the New Testament, and GNB (Good News Bible) for the corresponding translation of the whole Bible.

6. Rachel A. Kanyoro: "Inclusive Language and Bible Translation", unpublished paper.

7. Chicago, 2nd edition 1979 .

8. On this question, see E.A. Nida and W.D. Reyburn (1981) : Meaning across Cultures, N.Y., Maryknoll.

9. This article was completed early in 1985. For more recent discussion, see Alan Padgett (1986) : "Feminism in First Corinthians : A Dialogue with Elizabeth Schüssler Fiorenza", Evangelical Quarterly 58, pp. 121-132. 